\title{
THE RESPONSE OF RHEUMATIC AND NON-RHEUMATIC CHILDREN TO STREPTOLYSIN O CONCENTRATE ${ }^{1}$
}

\author{
BY ROBERT W. QUINN
}

\author{
(From the Department of Preventive Medicine and Public Health, Vanderbilt University, \\ School of Medicine, Nashville, Tenn.)
}

(Submitted for publication December 26, 1956; accepted February 14, 1957)

The observation that individuals who acquire rheumatic fever following a streptococcal infection usually respond with higher streptococcal antibody titres than those who have streptococcal infections uncomplicated by rheumatic fever has been reported repeatedly (1-7). There are exceptions, but, if rheumatics are considered as a group, this observation seems to hold true and it has led to an assumption that rheumatic individuals, that is, those who acquire rheumatic fever or are especially susceptible because one or both parents, a sibling or near relative has had rheumatic fever, respond in a different manner to streptococcal infections than non-rheumatic persons. The response of rheumatic and non-rheumatic subjects to antigenic stimuli has been the objective of several recent investigations (8-11) none of which has shown any significant differences between rheumatics and non-rheumatics in their response to a variety of non-streptococcal antigens with the exception that when a strain of Brucella abortus was used as the antigen $(12,13)$ rheumatic subjects developed higher levels of agglutinins and incomplete antibodies than normal persons. However, the more crucial question would seem to be : "Do rheumatics respond differently to streptococcal infections or antigens than non-rheumatics?" To conclude that rheumatic individuals respond with higher streptococcal antibody titres than non-rheumatics following a streptococcal infection because they are fundamentally different is open to a number of criticisms, one of which is that the dose of antigen in a streptococcal infection is unknown and it could be that some patients have higher antibody titres because they received a larger dose of antigen during the infection. It is the purpose of this paper to report an investigation of the problem of whether rheumatic individuals respond to equiva-

1 This study was aided by a grant from the Life Insurance Medical Research Fund. lent doses of streptococcal antigens in a different manner than non-rheumatic individuals.

\section{METHODS}

Preparation of streptolysin $O$ concentrate. A modification of a method for purification of streptolysin $O$ by Herbert and Todd (14) was used to prepare the concentrated streptococcal antigens. The starting material was the filtrate from 5 to 6 litres of beef heart infusion broth prepared from fresh beef hearts, in which a strain of group A type 3 beta hemolytic streptococcus had grown for 18 hours at $37^{\circ} \mathrm{C}$. Six lots of streptolysin O were prepared, the end-products of three preparations containing the most highly concentrated streptolysin $\mathrm{O}$ being combined. The steps in the purification procedure were the same as those outlined by Herbert and Todd with the exception that the final step of adsorption and elution from alumina $\mathrm{C}$ gamma gel was not performed. The final products were dry, fluffy, light $\tan$ to dark brown in color with some stickiness in two of the preparations. The yields were $26,102,35,208,187$ and 280 mg.

Test for streptolysin $O$ combining power. Five mg. of streptolysin $\mathrm{O}$ concentrate were dissolved in $1.0 \mathrm{ml}$. $\mathrm{M} / 15$ phosphate buffer $\mathrm{pH} 6.5$ containing $1.5 \mathrm{mg}$. L-cysteine $\mathrm{HCl}$ per ml. just prior to performing the test. The test was performed in a manner similar to that of Hodge and Swift (15). The mixed preparation used as antigen contained approximately 400 combining units per $\mathrm{ml}$. and for purposes of calculating equivalent doses was fixed arbitrarily at 400 combining units per ml. or 80 per mg. The preparation of $12 / 31 / 54$ had 100 combining units per ml. and the preparation of $1 / 10 / 55$ contained 12.5 combining units per $\mathrm{ml}$.

Test for the presence of streptokinase in the streptolysin $O$ concentrate. The method of Kaplan and his associates (16) was used to test for the presence of streptokinase. The preparation of $1 / 10 / 55$ showed complete clot lysis at a dilution of $1: 4$ and no lysis at $1: 8$ indicating the presence of a small amount of streptokinase. The mixed preparation was not actually tested for streptokinase but since it was prepared from the same strain of streptococcus it is assumed that it also contained a small amount of streptokinase.

Test for the presence of hyaluronidase in the streptolysin $O$ concentrate. A modification (17) of the method of McLean (18) was employed to test for hyaluronidase. In the preparation of $1 / 10 / 55$ there was no hyaluronidase 
TABLE I

Antistreptolysin $O$ levels in rabbits after streptolysin $O$ administration *

\begin{tabular}{|c|c|c|c|c|c|}
\hline \multirow{2}{*}{\multicolumn{2}{|c|}{$\begin{array}{l}\text { Rabbit No. } \\
\text { Dose and route } \\
\text { of administration }\end{array}$}} & \multirow{2}{*}{$\begin{array}{c}1 \\
10 \text { units SI"O"'† } \\
\text { intravenous } \\
\text { q } 3 \text { days } \times 9\end{array}$} & \multirow{2}{*}{$\begin{array}{c}2 \\
40 \text { units SI" } \mathrm{O}^{\prime \prime} \\
\text { intraperitoneal } \\
\mathbf{9} 3 \text { days } \times 9\end{array}$} & \multirow{2}{*}{$\begin{array}{c}3 \\
40 \text { units Sl"O" } \\
\text { intravenous } \\
93 \text { days } \times 9\end{array}$} & \multirow{2}{*}{$\begin{array}{c}4 \\
10 \text { units SI" "O" } \\
\text { intraperitoneal } \\
\text { q } 3 \text { days X } 9 \\
\end{array}$} \\
\hline & & & & & \\
\hline 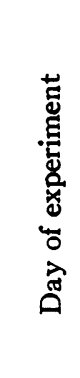 & $\begin{array}{r}0 \\
16 \\
28 \\
\\
31 \\
54 \\
54 \\
65 \\
106 \\
106 \\
121\end{array}$ & $\begin{array}{c}0 \\
0 \\
\text { Last dose of } \\
\text { antigen } \\
125 \\
40 \text { units Sl“O” } \\
\text { intradermal booster } \\
25 \\
25 \\
80 \text { units } \\
\text { intramuscular } \\
25 \\
83.3\end{array}$ & $\begin{array}{c}0 \\
50 \\
\text { Last dose of } \\
\text { antigen } \\
125\end{array}$ & $\begin{array}{c}0 \\
0 \\
\text { Last dose of } \\
\text { antigen } \\
62.5\end{array}$ & $\begin{array}{c}0 \\
20 \\
\text { Last dose of } \\
\text { antigen } \\
250 \\
40 \text { units Sl“O” } \\
\text { intradermal booster } \\
62.5 \\
62.5 \\
80 \text { units } \\
\text { intramuscular } \\
12.5 \\
>159\end{array}$ \\
\hline
\end{tabular}

* Numbers $=$ units of antistreptolysin 0 .

† $\mathrm{Sl}^{\prime \prime O} \mathrm{O}^{\prime \prime}=$ streptolysin $\mathrm{O}$.

and therefore it is assumed there was no hyaluronidase in any preparation.

Preparation of streptolysin $O$ concentrate for injection into rabbits and humans. The work of Todd (19) indicated that streptolysin in the reduced state is a better antigen than when not reduced; therefore, $1.5 \mathrm{mg}$. L-cysteine $\mathrm{HCl}$ per $\mathrm{ml}$. were added so that the streptolysin would be in a reduced state when injected. This vaccine contained approximately 40 combining units of streptolysin $\mathrm{O}, 500$ micrograms of protein or 80 micrograms nitrogen per $0.1 \mathrm{ml}$. of vaccine.

Test for antigenicity of the streptolysin $O$ concentrate. In order to determine if the streptolysin $O$ concentrate was antigenic, four young adult rabbits were injected by the routes and in the doses shown in Table I. It proved to be a very good antigen as shown by the antibody response which ranged from initial levels of zero to post immunization levels of 62.5 to 250 units of antistreptolysin $O$. The anticipated administration of the vaccine to humans was considered to be in the nature of a "booster" dose, since probably all of the human subjects would have had previous infections. Therefore, an attempt was made to determine the best route of injection of a booster dose in these rabbits to obtain the maximum antibody response. There was no response at all when the booster dose of antigen was administered intradermally or intraperitoneally but a very good response, from 25 to 83.3 and 12.5 to over 159 units of antistreptolysin $\mathrm{O}$ in two rabbits, when the route was intramuscular.

Route of injection and dose of streptolysin $O$ concentrate in experimental subjects. Before giving the streptolysin $O$ concentrate to children, the author injected 80 units intradermally into his right forearm. The next day, a large, tender, bright red, raised, swollen, indurated area $6 \times 11 \mathrm{~cm}$. was present about the injection site. Lymphangitis and lymphadenitis were present with malaise and fever. The area of erythema increased in size over a 2-day period and then gradually faded. Lymphangitis and lymphadenitis also gradually disappeared. The entire area desquamated after 2 weeks. (A small scar 4 to $5 \mathrm{~mm}$. in diameter remains at the injection site.) Two other adult volunteers $\mathrm{E}$. B. and $R$. H. received 8 and 16 units, respectively, intradermally, with similar but milder local and systemic reactions. After these experiences it was decided not to give any of the antigen intradermally but rather to use the intramuscular route.

The dose of streptolysin $\mathrm{O}$ concentrate was established arbitrarily according to the age of the subject. Children below the age of ten received 40 units with the exception of one large 10-year-old who received 60 units and two who received 8 units. Five non-rheumatics 11 years or older received 60 or more units, 16 received 40 units, 2 received 16 and 1 received 8 units. All but 3 of the rheumatic children 12 years or older received 60 units, the remaining 3 received 40,50 and 80 units.

Rheumatic subjects-20 children. Average age-10.8 years. None of these children had an upper respiratory infection within 2 months prior to receiving the antigen or for at least 3 weeks after the antigen. Characteristics of this group are shown in Table II.

Non-rheumatic subjects-55 children. Average age10.9 years. These normal children with no historical or physical evidence of rheumatic fever or rheumatic heart disease all received antigen. None had an upper respiratory infection of any kind for at least a month before or three weeks after receiving antigen and their throat cultures were negative for hemolytic streptococci.

Non-rheumatic children-45 children. Average age11.8 years. These non-rheumatic children served as additional controls and received no antigen. Thirteen children had no historical or clinical evidence of an upper respiratory infection within one month previous to the period of observation or during the three-week period of observation.

Thirty-two children had historical or clinical evidence of an upper respiratory infection one month previous to 
TABLE II

Rheumatic subjects

\begin{tabular}{|c|c|c|c|c|c|c|c|}
\hline Name & Age & Sex & Race & Diagnosis* & $\begin{array}{l}\text { Difference } \\
\text { in Asl" }{ }^{\prime \prime} \dagger \\
\text { titre }\end{array}$ & $\begin{array}{l}\text { Dose of } \\
\text { Sl"0"t }\end{array}$ & Reaction to antigen \\
\hline $\begin{array}{l}\text { D. L. } \\
\text { L.P. } \\
\text { L.F. } \\
\text { F. G. }\end{array}$ & $\begin{array}{l}6 \\
6 \\
7 \\
7\end{array}$ & $\begin{array}{l}\mathbf{M} \\
\mathbf{F} \\
\mathbf{F} \\
\mathbf{M}\end{array}$ & $\begin{array}{l}\mathrm{W} \\
\mathbf{W} \\
\mathbf{C} \\
\mathbf{W}\end{array}$ & $\begin{array}{l}\text { R.F. Inactive } \\
\text { R.F. Inactive } \\
\text { R.H.D. Inactive with MI } \\
\text { R.H.D. Inactive with MI }\end{array}$ & $\begin{array}{l}+1 \\
+3 \\
+1 \\
+1\end{array}$ & $\begin{array}{l}40 \\
40 \\
40 \\
40\end{array}$ & $\begin{array}{l}\text { Mild local tenderness. } \\
\text { None } \\
\text { Mild local reaction. } \\
\text { Edema, entire arm, tenderness, ery- } \\
\text { thema, induration } 3-4 \mathrm{~cm} \text {. about } \\
\text { injection. T. } 1044^{\circ} \mathrm{F} \text {. Fever } 3-4 \\
\text { days. }\end{array}$ \\
\hline W. P. & 8 & $\mathbf{M}$ & W & R.F. Inactive & +1 & 40 & $\begin{array}{l}\text { Edema, entire arm, tenderness, ery- } \\
\text { thema, induration 8-10 cm. 3-4 } \\
\text { days, T. } 100^{\circ} \mathrm{F} 2-3 \text { days. }\end{array}$ \\
\hline $\begin{array}{l}\text { J. B. } \\
\text { R. R. }\end{array}$ & $\begin{array}{r}9 \\
10\end{array}$ & $\begin{array}{l}\mathbf{M} \\
\mathbf{M}\end{array}$ & $\stackrel{\mathbf{W}}{\mathbf{C}}$ & $\begin{array}{l}\text { R.H.D. Inactive with MS } \\
\text { R.F. Inactive }\end{array}$ & $\begin{array}{l}+3 \\
+1\end{array}$ & $\begin{array}{l}40 \\
40\end{array}$ & $\begin{array}{l}\text { None } \\
\text { Local edema, tenderness, erythema. } \\
\text { T. } 102^{\circ} \mathrm{F} \text { Malaise. }\end{array}$ \\
\hline $\begin{array}{l}\text { R. A. } \\
\text { M. H. } \\
\text { G.J. } \\
\text { R. L. }\end{array}$ & $\begin{array}{l}10 \\
11 \\
11 \\
12\end{array}$ & $\begin{array}{l}\mathbf{M} \\
\mathbf{F} \\
\mathbf{F} \\
\mathbf{M}\end{array}$ & $\begin{array}{l}\mathrm{W} \\
\mathbf{C} \\
\mathbf{W} \\
\mathbf{W}\end{array}$ & $\begin{array}{l}\text { R.H.D. Inactive with MI } \\
\text { Chorea, probably inactive } \\
\text { R.H.D. ?Inactive MI } \\
\text { R.F. Inactive }\end{array}$ & $\begin{array}{r}+1 \\
0 \\
0 \\
+1\end{array}$ & $\begin{array}{l}40 \\
40 \\
40 \\
60\end{array}$ & $\begin{array}{l}\text { Sore arm } 3 \text { days. } \\
\text { Mild local tenderness. } \\
\text { Local edema and tenderness } 2 \text { days. } \\
\text { Severe local reaction with induration, } \\
\text { tenderness, erythema } 8-10 \mathrm{~cm} \text {. T. } \\
102^{\circ} \mathrm{F} 2 \text { days. }\end{array}$ \\
\hline W.P. & 12 & $\mathbf{M}$ & $\mathbf{w}$ & R.F. Inactive with ?MI & +6 & 60 & $\begin{array}{l}\text { Severe local reaction, swollen, tender } \\
\text { arm. T. } 104^{\circ} \mathrm{F} \text {. Fever } 4 \text { days. } \\
\text { Malaise } 4-5 \text { days. Arthritis. }\end{array}$ \\
\hline $\begin{array}{l}\text { E. E. } \\
\text { M. J. B. }\end{array}$ & $\begin{array}{l}12 \\
12\end{array}$ & $\stackrel{\mathbf{M}}{\mathbf{F}}$ & $\begin{array}{l}\mathrm{W} \\
\mathrm{W}\end{array}$ & $\begin{array}{l}\text { R.F. Probably inactive } \\
\text { R.F. Inactive }\end{array}$ & $\begin{array}{l}\mathbf{0} \\
\mathbf{0}\end{array}$ & $\begin{array}{l}60 \\
60\end{array}$ & $\begin{array}{l}\text { Mild local tenderness. } \\
\text { Local erythema, tenderness, indura- } \\
\text { tion, lymphadenopathy, nausea, } \\
\text { vomiting, T. } 102^{\circ} \mathrm{F} \text {. }\end{array}$ \\
\hline R. J. & 13 & $\mathbf{M}$ & W & $\begin{array}{l}\text { Chorea, Inactive } \\
\text { R.H.D. with AI and MI }\end{array}$ & -1 & 50 & Local tenderness 2 days. \\
\hline $\begin{array}{l}\text { M. K. } \\
\text { P. W. } \\
\text { M.J. } \\
\text { S. H. } \\
\text { C. S. }\end{array}$ & $\begin{array}{l}13 \\
14 \\
14 \\
15 \\
16\end{array}$ & $\begin{array}{l}\mathbf{F} \\
\mathbf{M} \\
\mathbf{F} \\
\mathbf{F} \\
\mathbf{M}\end{array}$ & $\begin{array}{l}\mathbf{C} \\
\mathbf{W} \\
\mathbf{C} \\
\mathbf{W} \\
\mathbf{W}\end{array}$ & $\begin{array}{l}\text { R.H.D. ?Inactive MS, MI } \\
\text { R.F. Inactive } \\
\text { R.H.D. Active with MI } \\
\text { R.H.D. Inactive with MI } \\
\text { R.F. Inactive }\end{array}$ & $\begin{array}{l}+1 \\
+1 \\
+4 \\
+1 \\
+3\end{array}$ & $\begin{array}{l}60 \\
60 \\
60 \\
60 \\
80\end{array}$ & $\begin{array}{l}\text { Local tenderness } 3 \text { days. } \\
\text { Local edema and tenderness } 2 \text { days. } \\
\text { Mild local tenderness } 1 \text { day. } \\
\text { None } \\
\text { Local tenderness } 2 \text { days. }\end{array}$ \\
\hline
\end{tabular}

* R.F. = Rheumatic Fever; R.H.D. = Rheumatic Heart Disease; MI = Mitral Insufficiency; MS = Mitral Stenosis; $\dot{A} I=$ Aortic Insufficiency.

$t$ Increase, decrease or no change in antistreptolysin $O$ titre by tube dilutions.

$\ddagger$ Streptolysin 0 concentrate in combining units.

the period of observation or during the three weeks of observation. Ten of these children received penicillin prior to the first examination. Throat cultures of 12 of these children were positive for hemolytic streptococci either at the time of examination or 3 weeks later. In three children there was clinical evidence of a throat infection at the time of examination.

A history was taken to determine if the subject ever had rheumatic fever. A physical examination was performed before the injection of antigen and 3 weeks later with special attention to the nasopharynx for clinical evidence of infections and to the cardiovascular system for evidence of rheumatic heart disease. The rheumatic children were all being followed in the Pediatric Heart Clinic of Vanderbilt Hospital and were all on sulfadiazine prophylaxis. Throat cultures were taken on every child at the beginning and again at the end of the three-week observation period. Other laboratory examinations of the rheumatic children included urinalysis, white blood cell count, packed cell volume, erythrocyte sedimentation rate, and C-reactive protein. Electrocardiograms were done only on four children. Blood specimens were drawn and laboratory examinations performed just before the antigen was given and again 21 days later. The serum was separated, merthiolate added to a concentration of $1: 10,000$ and stored at $4^{\circ} \mathrm{C}$. Each serum specimen was tested for antistreptolysin $\mathrm{O}$, antistreptokinase and antihyaluronidase.

\section{Serological methods}

Antistreptolysin $O$. The method of Hodge and Swift (15) was used. Each serum antistreptolysin $O$ titre was determined in duplicate by making one stock solution of 1:50 dilution and determining the titre of the stock dilution in duplicate tests on the same day. The greatest care was taken to eliminate any possible source of error. Sera were heated at $56^{\circ} \mathrm{C}$. for 30 minutes before the test. The serum dilutions were increased in $\log$ units by a factor of 0.1. Identical results were obtained from the duplicate titrations. In addition, antistreptolysin $O$ determinations on the rheumatic sera were made on different portions of each serum obtained from blood drawn at the same time. These determinations were done by a different technician at a different time in a different re- 


\section{ANTISTREPTOUYSN O TITERS OF BLOOD SERUM BEFORE AND 3 WEEKS AFTER INUECTION OF STREPTOUYSIN O CONCENTRATE}

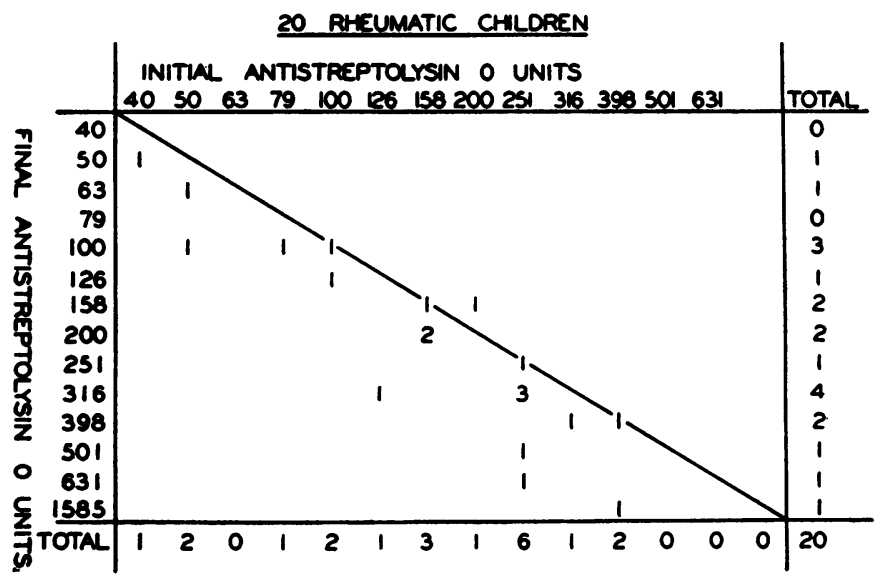

MERACE TITER BEFORE INECTION $=2.20 \pm .07$ (LOG UNITS) $=158$ CONBINING UNITS AVRACE TITER AFTER INJECTION $=2.34 \pm .08$ (LOG UNITS)-221 COMBINING UNITS AVERACE RISE $=0.145 \pm .038$ (LOG UNITS) $=63$ COMBINING UNITS

FIGURE 1.

search laboratory in the hospital. In 37 of $\mathbf{4 0}$ determinations the titres obtained by the two technicians were identical and in the remaining 3 the differences were only one dilution. These results lend strong support to the belief that the changes observed are real and not due to inherent error in the technique.

Antistreptokinase. The method of Kaplan and his associates (16) was employed but this test was not done in duplicate. The serum dilutions starting with $1: 25$ were based on a logarithmic scale in which each succes- sive dilution was increased by a factor of 1.5 as described by Kaplan.

Antihyaluronidase. A modification (17) of the method of McLean (18) was used for this test. The serum was diluted in distilled water using the same scale as for antistreptokinase.

\section{RESULTS}

The initial geometric mean of antistreptolysin $O$ titre for the 20 rheumatic children was 158

ANTISTREPTOLYSIN O TITERS OF BLOOD SERUM BEFORE AND 3 WEEKS AFTER INUECTION OF STREPTOLYSIN O CONCENTRATE

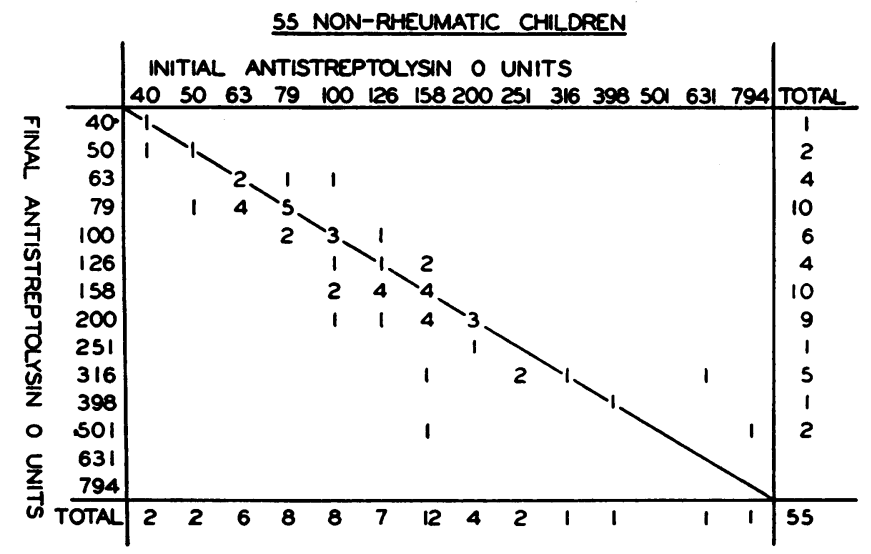

AVERAGE TITER BEFORE NUECTION $=2.08 \neq .04$ (LOG UNITS) $=121$ CONBNING UNITS ANERAGE TITER AFTER NUECTION $=2.13 \pm .03$ (LOG UNITS) $=135$ CONBINING UNITS AVERAGE RISE $=0.049 \pm 017$ (LOG UNITS) $=14$ COMBINING UNITS

Figure 2. 
ANTISTREPTOLYSIN O TITERS OF BLOOD SERUM

DETERMINED AT 3 WEEK INTERVALS

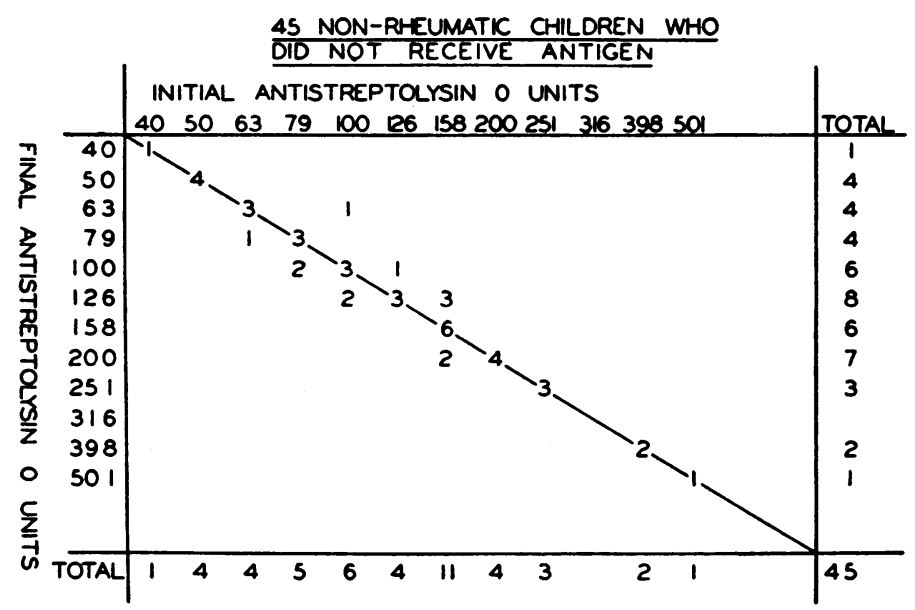

AVERAGE TITER, INITIAL SAMPLE $=2.09 \pm .04$ (LOG UNITS) $=123$ COMBINING UNITS AVERACE TITER, FINAL SAMPLE $=2.09 \pm .04$ (LOG UNITS) $=123$ CONBNING UNITS AVERAGE RISE $=0.002 \pm .009$ (LOG UNITS)

Figure 3.

combining units before the administration of antigen and for the 100 non-rheumatic children it was 121 units. The mean titres, while higher in the rheumatic children, had a probability level of 0.07 of being a random sampling difference and therefore the differences were not statistically significant. The distribution of the initial antistreptoly$\sin \mathrm{O}$ titres for 20 rheumatic children is shown in Figure 1.

Three weeks after the injection of streptolysin $O$ antigen, the levels for the rheumatic children had risen to a geometric mean titre of 221 combining units, a significant rise, although 5 of the children had shown no rise and only 5 had rises of two or more tubes in the dilution system. The antistreptolysin $O$ level of the 55 non-rheumatic children who received antigen rose from 121 to a geometric mean titre of 135 combining units three weeks after the antigen was injected (Figure 2). This is also a significant rise though 29 of the $\mathbf{5 5}$ children showed no rise and only seven had a rise of 2 or more tubes. The greater average antistreptolysin $O$ response of the rheumatic children to equivalent doses of streptolysin $\mathrm{O}$ concentrate was statistically significant $(P=0.01)$. The distribution of antistreptolysin $\mathrm{O}$ titres before and 3 weeks after injection of the streptolysin $\mathrm{O}$ concentrate is shown in Figure 2 for the 55 nonrheumatic children who received antigen. A group of 45 children who received no antigen was studied in the same manner as were the children who received antigen (Figure 3 ). Thirty-three of these children showed no change in antistreptolysin $\mathrm{O}$ titre during the three-week interval, seven had a 1-tube rise, four a 1-tube decrease and one a 2-tube decrease. The pre-and post-booster levels were 123 units. The percentage distribution of rise, no change, and decrease in antistreptolysin $\mathrm{O}$ titres shown in Figure 4 for rheumatic and nonrheumatic children who received antigen and the non-rheumatic children who did not receive antigen illustrates the tendency for the rheumatic children to respond with higher titres.

Correlation of the dose of antigen which each child received with the antistreptolysin $O$ response indicates that the antistreptolysin $\mathrm{O}$ response is not a function of the quantity of antigen, at least not in this dosage range, because the children who received the larger doses, 50 to 80 units of streptolysin $\mathrm{O}$, did not exhibit significantly higher antibody responses. Neither did the age of the children affect their response to streptolysin O concentrate significantly, because the titres of the children 11 or older were not significantly higher than the children 10 or younger, either in the rheumatic or non-rheumatic groups. The elapsed time since the onset of the most recent attack of rheumatic fever was not significantly dif- 


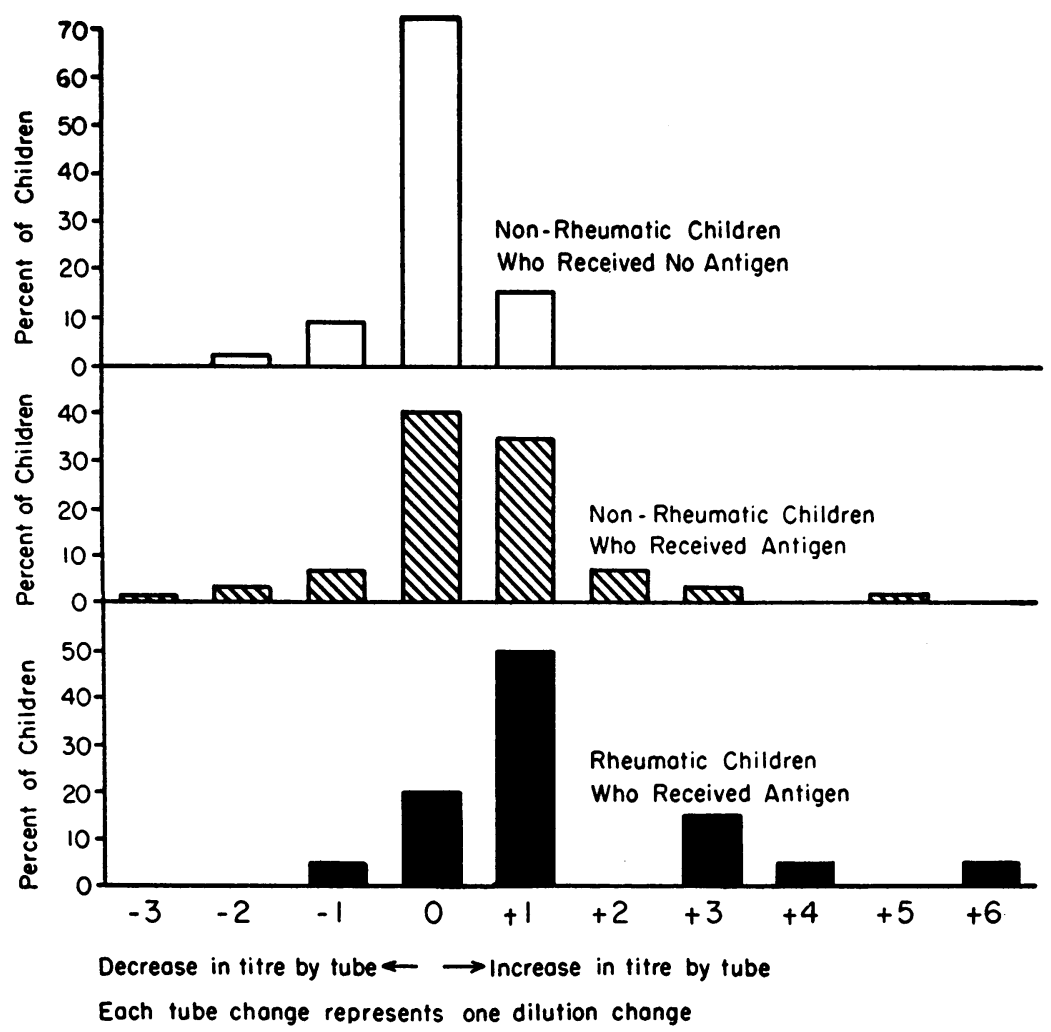

Figure 4.

ferent for those rheumatic children with a 3-tube or greater response (20.1 months' average) when compared with the rheumatic children with less than a 3-tube rise (17.1'months' average) not including two children whose onset of rheumatic fever was five and one-half and eight years previously.

The possibility does exist that the rheumatic and non-rheumatic groups might not be strictly comparable because the rheumatics had been on prophylaxis and did not have a streptococcal infection recently whereas for the non-rheumatic children who received antigen, all that can be said is that they did not have an upper respiratory infection of any kind within 1 month prior to receiving antigen nor during the 3-week period of observation and that their throat cultures were negative for hemolytic streptococci before and 3 weeks after the antigen was administered. ${ }^{2}$

2 If a decreasing antistreptolysin $\mathrm{O}$ titre is used as evidence of past streptococcal infection, that is, one which occurred several weeks or months ago, in contrast to a rising titre as evidence of an infection within the past
The geometric mean antistreptokinase titre of 159 units for 20 rheumatic children before antigen was administered was considerably higher than the mean of 148 units for 51 non-rheumatic children who received antigen and 100 units for 46 nonrheumatic children who received no antigen. However, a test for significant difference between mean titres for rheumatic and non-rheumatic children gives $P=0.22$, clearly not statistically significant. The titres rose following antigen in only three rheumatic children, the highest rise being

2 to 3 weeks, the data indicate that 7 of the 55 non-rheumatic children who received antigen had a decrease in titre compared with 1 of 20 rheumatic children. If the antistreptolysin $\mathrm{O}$ changes of the three non-rheumatic children who had a decrease in titre of 2 or more tubes are eliminated, a $t$ test comparing titre changes of 20 rheumatics with the remaining 52 non-rheumatics gives $P=0.021$, still a significant difference. If all seven of the non-rheumatic children who had a decrease in titre of 1 tube or more are eliminated along with one rheumatic child who had a 1-tube decrease, comparison of titre changes gives $\mathrm{P}=0.021$, again a significant difference. 
TABLE III

Changes in antistreptokinase titres

\begin{tabular}{|c|c|c|c|c|}
\hline $\begin{array}{l}\text { Change in } \\
\text { antistreptokinase } \\
\text { titres between initial } \\
\text { and final samples }\end{array}$ & $\begin{array}{l}20 \\
\text { rheumatic } \\
\text { children who } \\
\text { received } \\
\text { antigen }\end{array}$ & $\begin{array}{l}51 \\
\text { non-rheumatic } \\
\text { children who } \\
\text { received } \\
\text { antigen }\end{array}$ & $\begin{array}{l}46 \\
\text { non-rheumatic } \\
\text { children who } \\
\text { received no } \\
\text { antigen }\end{array}$ & Total \\
\hline $\begin{array}{l}\text { Two tubes lower } \\
\text { One tube lower } \\
\text { Same } \\
\text { One tube higher } \\
\text { Two tubes higher } \\
\text { Total }\end{array}$ & $\begin{array}{r}1 \\
0 \\
16 \\
2 \\
1 \\
20\end{array}$ & $\begin{array}{r}0 \\
2 \\
44 \\
4 \\
1 \\
51\end{array}$ & $\begin{array}{r}1 \\
1 \\
41 \\
2 \\
1 \\
46\end{array}$ & $\begin{array}{r}2 \\
3 \\
101 \\
8 \\
3 \\
117\end{array}$ \\
\hline
\end{tabular}

2 tubes (Table III). In one child the titre fell 2 tubes. Four non-rheumatic children who received antigen had a 1-tube rise, one a 2-tube rise and two a 1-tube decrease. In the non-rheumatic children who did not receive antigen the titres rose 1 tube in two children, 2 tubes in one child and decreased 1 and 2 tubes in two children. The small rises observed in only three rheumatic children and five non-rheumatic children who received antigen are not significantly different from the changes in titres observed in the children who did not receive antigen.

The "pre-booster" antihyaluronidase titres were distributed in a manner similar to those for antistreptolysin and antistreptokinase, i.e., the mean initial levels were consistently higher for the rheumatic than the non-rheumatic children being $1: 248$, $1: 174$ and $1: 177$ for the three groups respectively. Three weeks following the streptolysin $\mathrm{O}$ concentrate, among the rheumatic children the titre remained the same in 17 , rose 1 tube in one child and diminished 1 tube in two children (Table IV). Among 50 non-rheumatic children who received antigen, titres did not change in 38 , rose 1 tube in five of them, 3 tubes in one and diminished 1 tube in five and 2 tubes in one. Of the 46 non-rheumatic children who received no antigen, titres for serum obtained three weeks after the first specimen were the same for 37 , increased in three children, 1,2 , and 3 tubes, decreased 1 tube in five of them and 2 tubes in one.

Six of the rheumatic children and one of the non-rheumatics had severe reactions with local and systemic manifestations. These reactions were characterized by tenderness and edema gradually involving the entire arm, extensive erythema and increased temperature about the injection site and pain of the entire arm, all of these manifestations beginning 2 to 12 hours after the injection and increasing in area and severity for about 48 hours, thereafter decreasing. The systemic reaction began at the same time and consisted of fever lasting usually 3 days, but for 5 days in one child, reaching a maximum of 102 to $105^{\circ} \mathrm{F}$, generalized malaise, anorexia, vomiting in one child and pain and tenderness in an interphalangeal joint of the hand opposite the injection side in one child. The remainder of the rheumatic and non-rheumatic children who received antigen had either no noticeable reaction or mild to moderate tenderness and

TABLE IV

Changes in antihyaluronidase titres

\begin{tabular}{|c|c|c|c|c|}
\hline $\begin{array}{c}\text { Change in } \\
\text { antihyaluronidase } \\
\text { titres between initial } \\
\text { and final samples }\end{array}$ & $\begin{array}{l}20 \\
\text { rheumatic } \\
\text { children who } \\
\text { received } \\
\text { antigen }\end{array}$ & $\begin{array}{c}50 \\
\text { non-rheumatic } \\
\text { children who } \\
\text { received } \\
\text { antigen }\end{array}$ & $\begin{array}{l}46 \\
\text { non-rheumatic } \\
\text { children who } \\
\text { received no } \\
\text { antigen }\end{array}$ & Total \\
\hline $\begin{array}{l}\text { Two tubes lower } \\
\text { One tube lower } \\
\text { No change } \\
\text { One tube higher } \\
\text { Two tubes higher } \\
\text { Three tubes higher } \\
\text { Total }\end{array}$ & $\begin{array}{r}0 \\
2 \\
17 \\
1 \\
0 \\
0 \\
20\end{array}$ & $\begin{array}{r}1 \\
5 \\
38 \\
5 \\
0 \\
1 \\
50\end{array}$ & $\begin{array}{r}1 \\
5 \\
37 \\
1 \\
1 \\
1 \\
46\end{array}$ & $\begin{array}{r}2 \\
12 \\
92 \\
7 \\
1 \\
2 \\
116\end{array}$ \\
\hline
\end{tabular}


erythema about the injection site. The occurrence of a severe reaction in six of the rheumatic children and only one non-rheumatic would seem to be of significance; at any rate because of these severe reactions the decision was made not to give the antigen to any more rheumatic children. There was no clinical or laboratory evidence of reactivation of rheumatic fever in any of the inactive rheumatics, exacerbation of rheumatic fever in any of the active rheumatics, or initiation of rheumatic fever in any of the non-rheumatics. The C-reactive protein reaction did not become positive in any rheumatic child after antigen administration. Three of these children received 40 units and three 60 units of antigen; one had a 6-tube rise, five a 1-tube rise and one had no rise in antistreptolysin $\mathrm{O}$.

\section{DISCUSSION}

The finding that the children with rheumatic fever responded as a group with significantly higher antistreptolysin $\mathrm{O}$ titre rises than nonrheumatic children following equivalent doses of streptolysin $\mathrm{O}$ would be of greater significance if all the rheumatic children and none of the nonrheumatics had reacted in this manner. If rheumatic subjects are all fundamentally different in respect to the manner in which they respond to streptococcal infections or antigens, it might be expected that they would all exhibit higher antibody rises. An explanation of these findings does not necessarily lie in any inherent difference in the manner in which rheumatic children respond to streptococcal antigens. The individual's past experience with the hemolytic streptococcus, that is, the total number and severity of infections and the elapsed time since the most recent infection certainly determines in part the magnitude of clinical and antibody response. However, only 5 of the 20 rheumatic children studied responded with large rises in titre and if these five are eliminated there would have been no significant differences between the rheumatics and non-rheumatics.

The absence in all but two children of significant rises in antistreptokinase titres following the injection of an antigen containing a very small amount of streptokinase suggests the amount of antigen may have been too small to stimulate an antibody response. The work of Christensen (20) and Tillet and Sherry (21) leaves no doubt that streptokinase is antigenic. Antihyaluronidase titres rose significantly in only two children who received antigen. The failure to demonstrate consistent rises in either antistreptokinase or antihyaluronidase levels during the period of observation is evidence that non-specific and anamnestic antibody responses did not occur and is in accord with the observations of Kuhns and McCarty (10) that non-specific antibody responses do not occur.

The changes in antistreptolysin $\mathrm{O}$ titres which took place in the non-rheumatic children who did not receive streptolysin $\mathrm{O}$ indicate that antistreptolysin $\mathrm{O}$ levels are continually changing in some children. Whether the titre is rising or falling or remaining stationary probably depends on how recently the child has had a streptococcal infection. The marked changes which occur in this and other streptococcal antibodies in normal children over a period of time has been observed previously $(22,23)$.

The streptolysin $\mathrm{O}$ concentrate evoked a marked systemic reaction in only 1 of 55 non-rheumatic children whereas 6 of 20 rheumatic children reacted severely to an equivalent dose. This striking difference indicates that some rheumatic children, as least, react systemically as well as in their antibody response in a manner significantly different from non-rheumatics; however, only one of these six had an ununusally high antistreptolysin $\mathrm{O}$ response. The meaning of this difference is not clear nor is the cause, but one cannot help wondering if the experience of these few children with the hemolytic streptococcus either in the recent or distant past might have been different from the others. That is, if these seven children who had severe reactions had unusually numerous streptococcal infections, would they be more likely to have a more severe systemic reaction or respond with higher antibody levels than those who had fewer or more distant infections? The elapsed time since the most recent attack of rheumatic fever and presumably the last streptococcal infection was not significantly different for the "severe reactions," and time per se did not seem to determine which of the rheumatic children would react most severely or would exhibit the highest antibody responses.

The findings of this study are similar to others which have attempted to show a direct relation- 
ship between rheumatic fever and streptococcal infections; the results although suggestive are not conclusive. Some of these rheumatic children reacted differently to the streptolysin antigen, but some did not. Possibly susceptibility to rheumatic fever is a changing process similar to immunity against certain infections and if such antigen-response measurements could be made at a time when the rheumatic children are highly susceptible (whenever that might be) clear-cut, conclusive differences might be shown.

\section{SUM MARY}

Streptolysin O concentrate was prepared and administered intramuscularly to 20 children with rheumatic fever and 55 non-rheumatic children. Another group of 45 non-rheumatic children served as an additional control. The children were carefully observed clinically and antistreptolysin $\mathrm{O}$, antistreptokinase and antihyaluronidase titres were determined before and 3 weeks after administration of the antigen.

The initial geometric mean antistreptolysin $\mathrm{O}$ titre of 158 combining units for the rheumatic children was higher than the initial mean titre of 121 for 100 non-rheumatic children; this difference is not statistically significant.

Initial antistreptokinase and antihyaluronidase titres were higher for the rheumatic children than the non-rheumatic but the differences were not great. No significant rise in either of these mean antibody levels following antigen occurred, indicating that non-specific or anamnestic antibody responses did not occur following streptolysin $\mathrm{O}$ administration. Six rheumatic and one nonrheumatic child had rather severe local and generalized reactions to the antigen. No evidence of initiation or reactivation of rheumatic fever was observed.

The results indicate that, as a group, the children with rheumatic fever reacted more severely and had greater antistreptolysin $O$ responses following the intramuscular injection of streptolysin $O$ concentrate than the non-rheumatic children. The significance or reasons for the findings are not clear, but the results do support previous clinical observations that rheumatic children frequently but not always respond with higher antibody lev- els following a streptococcal infection than nonrheumatic children.

\section{ACKNOWLEDGMENT}

The technical assistance of Mrs. Betty Horn and Mr. James Wilson and the statistical analyses done by $\mathrm{Mr}$. Edwin B. Bridgforth are gratefully acknowledged.

\section{REFERENCES}

1. Windblad, S., Studies in haemolytic streptococcus fibrinolysin, antifibrinolysin, and antistreptolysin with particular reference to rheumatic fever. Acta path. et microbiol. Scandinav., 1941, Supp. 44, 1.

2. Kalbak, K., Experimentelle og Kliniske Unders $\varnothing$ gelser over O-Streptolysin og Forekomsten af O-Antistreptolysin I Serum med saerlig Henblik paeforholdet ved Polyarthritis Rheumatica Acuta. With an English summary. Ejnar Munksgaards Forlag, København, 1942.

3. Rothbard, S., Watson, R. F., Swift, H. F., and Wilson, A. T., Bacteriologic and immunologic studies on patients with hemolytic streptococcic infections as related to rheumatic fever. Arch. Int. Med., 1948, 82, 229.

4. Quinn, R. W., Antihyaluronidase studies of sera from patients with rheumatic fever, streptococcal infections, and miscellaneous non-streptococcal diseases. J. Clin. Invest., 1948, 27, 471.

5. Harris, T. N., and Harris, S., Studies in the relation of the hemolytic streptococcus to rheumatic fever. V. Streptococcal anti-hyaluronidase (mucin-clotprevention) titers in the sera of patients with rheumatic fever, streptococcal. Am. J. M. Sc., 1949, 217, 174.

6. Anderson, H. C., Kunkel, H. G., and McCarty, M. J., Quantitative antistreptokinase studies in patients infected with group A hemolytic streptococci: A comparison with serum antistreptolysin and gamma globulin levels with special reference to the occurrence of rheumatic fever. J. Clin. Invest., 1948, 27, 425.

7. Denny, F. W., Wannamaker, L. W., and Rammelkamp, C. H., The relation of antibody production to the development of rheumatic fever. Am. J. Dis. Child., 1950, 80, 506.

8. Miller, J. M., Kibrick, S., and Massell, B. F., Antibody response to non-streptococcal antigens as related to rheumatic fever susceptibility. J. Clin. Invest., 1953, 32, 691.

9. Quinn, R. W., Seastone, C. V., and Dickie, H. A., Antibody production and tuberculin sensitivity in individuals with a history of rheumatic fever. J. Immunol., 1953, 70, 493.

10. Kuhns, W. J., and McCarty, M., Studies of diphtheria antitoxin in rheumatic fever subjects: Analysis of reactions to the Schick test and of antitoxin responses following hyperimmunization with diphtheria toxoid. J. Clin. Invest., 1954, 33, 759. 
11. Quinn, R. W., The antitoxin response of Schicknegative rheumatic and non-rheumatic subjects to diphtheria toxoid. J. Immunol., 1956, 76, 246.

12. Wagner, V., and Rejohlec, V., Agglutinins and incomplete antibodies after a single antigenic inoculation in normal and rheumatic individuals. Ann. Rheumat. Dis., 1955, 14, 243.

13. Padovcova, H., Rejholec, V., Suda, F., and Wagner, V., Immunologic reactivity in rheumatic fever; response of agglutinins and incomplete antibodies to a single antigenic impulse in ten-year-old children. Ann. Pediat., 1956, 187, 35.

14. Herbert, D., and Todd, E. W., Purification and properties of a haemolysin produced by group A haemolytic streptococci (Streptolysin O). Biochem. J., 1941, 35, 1124.

15. Hodge, B. E., and Swift, H. F., Varying hemolytic and constant combining capacity of streptolysins; influence on testing for antistreptolysins. J. Exper. Med., 1933, 58, 277.

16. Kaplan, M. H., in collaboration with The Commission on Acute Respiratory Disease, Studies of streptococcal fibrinolysis. III. A quantitative method for the estimation of serum antifibrinolysin. J. Clin. invest., 1946, 25, 347.

17. Quinn, R. W., Studies of the mucin-clot prevention test for the determination of the antihyaluronidase titre of human serum. J. Clin. Invest., 1948, 27, 463.

18. McLean, D., Studies in diffusing factors. II. Methods of assay of hyaluronidase and their correlation with skin diffusing activity. Biochem. J., 1943, 37, 169.

19. Todd, E. W., Antigenic streptococcal hemolysin. J. Exper. Med., 1932, 55, 267.

20. Christensen, L. R., Methods for measuring the activity of components of the streptococcal fibrinolytic system, and streptococcal desoxyribonuclease. J. Clin. Invest., 1949, 28, 163.

21. Tillet, W. S., and Sherry, S., The effect in patients of streptococcal fibrinolysin (streptokinase) and streptococcal desoxyribonuclease on fibrinous, purulent, and sanguinous pleural exudations. J. Clin. Invest., 1949, 28, 173.

22. Quinn, R. W., Liao, S. J., and Quinn, J. P., Antistreptolysin "O", antihyaluronidase and streptococcal agglutinin titers in seventh and eighth grade school children from two Connecticut cities. Am. J. Hyg., 1951, 54, 331.

23. Saslaw, M. S., and Streitfeld, M. M., Group A beta hemolytic streptococci in relation to rheumatic fever. Am. J. Dis. Child., 1956, 92, 550. 